University of Michigan Law School

University of Michigan Law School Scholarship Repository

1995

\title{
Physician Assisted Suicide: The Last Bridge to Active Voluntary Euthanasia
}

\author{
Yale Kamisar \\ University of Michigan Law School, ykamisar@umich.edu
}

Available at: https://repository.law.umich.edu/book_chapters/56

Follow this and additional works at: https://repository.law.umich.edu/book_chapters

Part of the Constitutional Law Commons, Courts Commons, Medical Jurisprudence Commons, and the Supreme Court of the United States Commons

\section{Publication Information \& Recommended Citation}

Kamisar, Yale. "Physician Assisted Suicide: The Last Bridge to Active Voluntary Euthanasia." In Euthanasia Examined: Ethical, Clinical and Legal Perspectives, edited by J. Keown, 225-60. Cambridge: Cambridge Univ. Press, 1995.

This Book Chapter is brought to you for free and open access by the Faculty Scholarship at University of Michigan Law School Scholarship Repository. It has been accepted for inclusion in Book Chapters by an authorized administrator of University of Michigan Law School Scholarship Repository. For more information, please contact mlaw.repository@umich.edu. 


\title{
15
}

\section{Physician-assisted suicide: the last bridge to active voluntary euthanasia}

\author{
YALE KAMISAR
}

SOME 30 YEARS AGO an eminent constitutional law scholar, Charles L. Black, Jr, spoke of 'toiling uphill against that heaviest of all argumental weights - the weight of a slogan. ${ }^{1}$ I am reminded of that observation when I confront the slogan the 'right to die.'

\section{THE 'RIGHT TO DIE'}

Few rallying cries or slogans are more appealing and seductive than the "right to die.' But few are more fuzzy, more misleading, or more misunderstood. The phrase has been used loosely by many people to embrace at least four different rights:

I the right to reject or to terminate unwanted medical procedures, including life-saving treatment;

2 the right to commit suicide or, as some call it, the right to 'rational' suicide;

3 the right to assisted suicide, that is, the right to obtain another's help in committing suicide; and

4 the right to active voluntary euthanasia, that is, the right to authorize another to kill you intentionally and directly.

Each of these four 'rights' should be kept separate and distinct. Unfortunately, many times they are not.

First of all, neither the 1976 Quinlan case ${ }^{2}$ nor the 1990 Cruzan case (the $^{3}$ only case involving death, dying and the 'right to privacy' ever decided by the 
US Supreme Court) establishes an absolute or general right to die - a right to end one's life in any manner one sees fit. The only right or liberty that the Quinlan Court established and the Cruzan Court recognized is the right under certain circumstances to refuse or to reject life-sustaining medical treatment or, as many have called it, the right to die a natural death.

Indeed, the Quinlan case explicitly distinguished between letting die on the one hand, and both direct killing and assisted suicide on the other. ${ }^{4}$ No less prominent an advocate of assisted suicide and active voluntary euthanasia than the Hemlock Society's Derek Humphry recognizes that the Quinlan case 'is significant,' inter alia, for 'distinguishing between suicide and the passive withdrawal of life supports.'s

As did Quinlan, the Cruzan case, the one 'right to die' case that rivals Quinlan for prominence, involved the right to end artificial life support. ${ }^{6}$ Cruzan, too, provides small comfort to proponents of a constitutional right to assisted suicide.

In Cruzan, a 5-4 majority, per Chief Justice Rehnquist, 'assumed for purposes of this case' that a competent person has 'a constitutionally protected right to refuse lifesaving hydration and nutrition. ${ }^{77}$ But the Court declined to call the liberty a 'fundamental right,' a characterization that requires a state to provide a compelling justification before restricting it. Instead, the Court called the right 'a Fourteenth Amendment liberty interest.'8

By avoiding 'fundamental right' language, the Court, it seems, would permit a state to restrict the 'liberty interest' in terminating unwanted life-sustaining medical treatment upon a lesser showing of need than would have been required if the interest had been deemed 'fundamental.' 'Any reasonable state interest' might suffice. ${ }^{9}$ In any event the Cruzan Court did not assume or even suggest that one has so much as a 'Fourteenth Amendment liberty interest' in assisted suicide. Quite the contrary. The Court asserted that a state has an undeniable interest 'in the protection and preservation of human life' and supported this assertion by noting:

[T] he majority of States in this country have laws imposing criminal penalties on one who assists another to commit suicide. We do not think a State is required to remain neutral in the face of an informed and voluntary decision by a physically able adult to starve to death. ${ }^{10}$

I share the view that the language quoted above amounts to an endorsement of laws prohibiting assisted suicide (and laws permitting state intervention to prevent suicide). ${ }^{11}$

Cruzan is not the only Supreme Court case on which proponents of a right to assisted suicide rely. They also find support for their views in the Court's abortion cases. ${ }^{12}$ In Roe v. Wade, ${ }^{13}$ the Court informed us that 'a right of 
privacy, or a guarantee of certain areas or zones of privacy,' which had earlier been invoked to invalidate restrictions on the use of contraceptives, 'is broad enough to encompass a woman's decision whether or not to terminate her pregnancy. ${ }^{14}$ The Court cleared the way for its ultimate holding by rejecting the state's argument that 'a fetus is a person' within the meaning of the Constitution - "the word "person," as used in the Fourteenth Amendment, does not include the unborn.'15

Although Roe did not concern the termination of a human life, as the Court perceived the matter, the case has been read very broadly to support a 'right' or 'liberty' to commit suicide and to enlist the assistance of others in doing so. ${ }^{16}$ So far as I am aware, however, no one who has read $R o e$ this broadly has taken into account that later in the same Term the Court rejected the notion that 'our Constitution incorporates the proposition that conduct involving consenting adults only is always beyond state regulation. ${ }^{17}$ It is noted at this point that ' $[t]$ he state statute books are replete with constitutionally unchallenged laws against prostitution, suicide ... and duels, although these crimes may only directly involve "consenting adults." 18

The Court must have meant assisted suicide, not suicide, for two reasons: (I) suicide itself does not involve consenting adults; and (2) at the time the Court made this observation there were no state laws against suicide, but there were many criminalizing assisted suicide.

A plausible argument may be made that the 'right of privacy' which protects a woman's right to terminate her pregnancy, at least in its early stages, includes the 'right' or 'liberty' of a person, at least one terminally ill, to make the choice whether to continue to live until death comes naturally or to hasten death by the use of 'physician-prescribed medications.' ${ }^{19}$ But a much more persuasive argument may be made, I believe, that the 'right of privacy' invoked in Roe encompasses the autonomy of sexual activity and relationships.

As Justice Blackmun wrote in a much-publicized consensual sodomy case, '[s] exual intimacy is "a sensitive, key relationship of human existence, central to . . . the development of human personality" '; "individuals define themselves in a significant way through their intimate sexual relationships with others' and 'much of the richness of a relationship will come from the freedom an individual has to choose the form and nature of these intensely personal bonds. ${ }^{20}$ But Justice Blackmun wrote in dissent.

A majority of the Court in that case, Bowers v. Hardwick, upheld the challenged ban against consensual sodomy as applied to homosexuals even though the activity took place in private. Roe and other 'right of privacy' cases were explained away on the ground that they involved family, marriage, procreation, contraception and abortion. ' $[A]$ ny claim that these cases ... stand for the proposition that any kind of private sexual conduct between 
consenting adults is constitutionally insulated from state proscription is unsupportable.'21

Robert Sedler, a well-known law professor and one of the lawyers challenging the constitutionality of Michigan's prohibition against assisted suicide, maintains that "the essence of the "liberty" protected by the due process clause is personal autonomy' which, he contends, encompasses a person's right 'to control his or her own body, and to define his or her own existence' (which, he claims, includes the right to end one's existence in accordance with one's principles). ${ }^{22}$ How does or can Professor Sedler reconcile his views with Bowers v. Hardwick, which rejected a similar argument in the context of sexual activities and relationships? A sphere of conduct like that at issue in Hardwick seems much closer to marriage, procreation, the use of contraceptives and abortion than the right to assisted suicide. Sedler does not attempt to reconcile his views with Bowers v. Hardwick. He ignores the case entirely.

\section{COMPARING AND CONTRASTING SUICIDE, ASSISTED SUICIDE AND ACTIVE EUTHANASIA}

\section{The right to active voluntary euthanasia}

In recent decades we have witnessed a good deal of change in attitudes toward death and dying, especially 'letting die.' But it is no less true today than it ever was that active voluntary euthanasia (sometimes called 'consensual homicide') is murder. Although there has long been a high incidence of failures to indict and jury nullification in these cases, ${ }^{23}$ the law on the books in every state is clear: If one intentionally and actively kills another, neither the fact that he did so at the deceased's request nor the fact that the defendant was motivated by 'mercy' excuses the homicide. One cannot waive one's right not to be killed. ${ }^{24}$

To be sure, some commentators have forcefully argued that one should be able to waive one's right not to be killed, at least where the person is competent and makes an 'informed' decision that continued existence is no longer desirable or sensible under the circumstances. ${ }^{25}$ But to date no American legislature nor any American court has accepted this argument in the context of active voluntary euthanasia.

\section{The right to assisted suicide}

Assisted suicide falls somewhere between the termination of life support and active voluntary euthanasia. (More about just where it falls later.) Active 
voluntary euthanasia occurs when a person other than the one who dies performs the last act - the one that actually brings about death. Assisted suicide takes place when another person provides assistance but the suicidant commits the last act herself. Although the two practices differ with respect to who performs the 'last act,' they are similar in that each involves the active intervention of another person to promote or to bring about death.

As the Cruzan Court noted, assisted suicide (although less widely condemned than active voluntary euthanasia) is a crime in a majority of American states. Most of the states that prohibit assisted suicide do so by specific legislation, while some treat it as a form of murder or manslaughter. ${ }^{26}$

\section{Suicide, attempted suicide and assisted suicide}

It is often said that since there is a 'right' to commit suicide it follows that there is a right to assisted suicide as well. But I do not think if fitting or proper to speak of a right to commit suicide.

Although one usually has the capacity to commit suicide, one does not have the right to do so. The fact that we no longer punish suicide or attempted suicide does not mean that we approve of these acts or that we recognize that an individual's right to 'self-determination' or 'personal autonomy' extends this far.

The decriminalization of both suicide and attempted suicide did not come about because suicide was deemed a 'human right' or even because it was no longer considered objectionable. Rather, it occurred because punishment was seen as unfair to innocent relatives of the suicide and because those who committed or attempted to commit the act were thought to be prompted by mental illness. ${ }^{27}$ However, the judgment that there is no form of criminal punishment that is acceptable for a completed suicide and that criminal punishment is singularly inefficacious to deter attempts to commit suicide does not mean that there is a 'right' to commit the act. Much less does it mean that one has a justifiable claim to assistance in committing the act. ${ }^{28}$

That criminal punishment was thought to have no deterrent effect on would-be suicides does not mean it would be ineffective in the case of someone considering assisting another to commit suicide. And there is good reason to invoke the criminal law in the latter case: '[T]he interests in the sanctity of life' represented by the prohibition against criminal homicide would seem to be 'threatened by one who expresses a willingness to participate in taking the life of another, even though the act may be accomplished with the consent, or at the request of, the suicide victim.' ${ }^{29}$

This, at least, was the judgment of the eminent scholars who drafted the American Law Institute's Model Penal Code (hereinafter the Code) in the 
I950s and I960s. The Code is considered 'the principal text in criminal law teaching, the point of departure for criminal law scholarship, and the greatest single influence on the many new state codes that have followed in its wake. ${ }^{30}$ Although it criminalizes neither suicide nor attempted suicide, it does make aiding or soliciting another to commit suicide a felony. ${ }^{31}$

The Code's reporters considered the argument that in certain cases the criminality of assisted suicide should turn upon 'the presence of a selfish motive' - a position advanced by one of its special consultants, Glanville Williams, a renowned British commentator and a leading proponent of assisted suicide and voluntary euthanasia. In the end, however, the reporters concluded that 'the wiser course' in these cases 'is to maintain the prohibition and rely on mitigation in the sentence when the ground for it appears. ${ }^{32}$

Recently, a proponent of physician-assisted suicide asked: 'How should the law respond when a physician or other person helps an individual do something that is legal in every state, when that legal activity is suicide? ${ }^{33}$ It may be good advocacy to frame the question this way, but to do so strikes me as quite misleading.

As already pointed out, the reasons that led to the decriminalization of suicide and attempted suicide do not apply when one person 'helps' another to commit suicide. Although there may be 'a certain moral extravagance in imposing criminal punishment on a person who has sought his own self-destruction [and] who more properly requires medical or psychiatric attention,' ${ }^{34}$ self-destruction 'is still a harm to be avoided, not a right to be encouraged. ${ }^{35}$ That is why, despite the fact that suicide itself is no longer a crime, 'helping' another commit suicide - if 'help' means 'intentionally providing the physical means' or 'intentionally participat[ing] in a physical act' by which that other person dies by suicide ${ }^{36}$ - remains a crime in most states.

\section{WOULD A NARROW EXCEPTION TO CURRENT CRIMINAL PROHIBITIONS REMAIN A NARROW EXCEPTION FOR VERY LONG?}

\section{Assisted suicide versus active voluntary euthanasia}

Consider the following cases: A competent patient who has clearly made known her wish to die accomplishes her purpose by swallowing a lethal dose of medication which her physician has $(a)$ placed under her pillow or on the night table next to her bed; $(b)$ placed in her hand; $(c)$ put in her mouth. How should we characterize these cases? 
It is fairly clear that $(a)$ constitutes assisted suicide, but what of cases $(b)$ and $(c)$ ? I would say that $(b)$ is also a case of assisted suicide because the lethal process has not yet become irreversible. The patient still has a choice - she could change her mind before putting the medication in her mouth and swallowing it. I think case $(c)$ is a very close call, but even here one could argue that this, too, is an act of assisted suicide - if the patient is able to remove the substance from her mouth or spit it out, but instead chooses to swallow it. If so, then even here, one could argue, the patient still retains the final choice.

Lawrence Gostin, the Editor-in-Chief of the Journal of Law, Medicine and Ethics, would disagree with me. He would say that both $(b)$ and $(c)$ should be classified as active euthanasia because in both cases the physician did not merely take part in the events leading up to the commission of the suicide but 'active[ly] participat[ed] in an overt act directly causing death. ${ }^{37}$ (But if this can be said of the physician who puts a lethal dose of medication in a patient's hand, why can it not also be said of the doctor who places the medication within a patient's easy reach?)

Whether one agrees with Gostin or me does not matter very much. What does matter, I think, is that the distinctions among these closely related acts are so fine that reasonable people (if I may include myself in that group) cannot agree on which side they fall. ${ }^{38}$

If so, how can these distinctions be defended on principle or maintained in practice? Once we cross the line between the termination of life support and the active intervention of another to promote or to bring about death, how can we - and why should we - stop short of active voluntary euthanasia?

One who turns to the literature on the law and morality of assisted dying soon discovers that the line between assisted suicide and voluntary euthanasia is often blurred and sometimes completely obliterated. Voluntary euthanasia 'has been variously described as "assisted suicide"' and suicide has sometimes been called 'self-administered euthanasia., ${ }^{39}$ According to one leading writer on the subject, active voluntary euthanasia is 'a form of suicide' and the case for voluntary euthanasia 'depends upon the case for the righteousness of suicide. ${ }^{40}$ Another commentator similarly maintains that 'the permissibility of euthanasia follows from the permissibility of suicide. ${ }^{41}$ Still another considers voluntary euthanasia 'essentially a form of suicide involving the assistance of others.'42

The fine distinction between assisted suicide and voluntary euthanasia who performs the 'last act' - was badly smudged by the hard-fought campaigns in the states of Washington (r99I) and California (1992) to legalize physician 'aid-in-dying' - a label covering both assisted suicide and 
active voluntary euthanasia. ${ }^{43}$ I followed both campaigns very closely and came away with the impression that many members of the media and general public either did not understand the distinction between the two practices or did not accept it.

Derek Humphry, the founder of the Hemlock Society, has probably written more about the general subject than anyone else, and his books have undoubtedly been read by more people than any others in the field. He uses the terms suicide, assisted suicide, euthanasia and self-deliverance quite loosely and almost interchangeably.

In a recent book, Dying with Dignity, Humphry tells his readers that he had 'no knowledge or interest in euthanasia' until he helped his first wife die by furnishing her 'a lethal potion of drugs with which she could end her life at a time chosen by her. ${ }^{34}$ Thirty pages later he describes this incident as a personal 'euthanasia experience.' 45 At another point he tells us that 'justifiable suicide' is 'rational and planned self-deliverance' or 'autoeuthanasia. ${ }^{\mathbf{4 6}}$ Some ninety pages later he recalls that before the advent of Hemlock 'active voluntary euthanasia (also known as self-deliverance and autoeuthanasia) was a taboo subject in America.' ${ }^{47}$ In a chapter on 'Euthanasia for the Elite,' he maintains that 'euthanasia is already widely available to the elite,' because ' $[w]$ ell off or well connected people often have medical friends who, in secret, will pass out lethal drugs or actually make the injection. ${ }^{38}$

Some, no doubt, would dismiss Derek Humphry as a 'popularizer.' But then they must deal with the eminent lawyer-philosopher, Ronald Dworkin. On the opening page of his new book, Life's Dominion, Professor Dworkin observes:

The argument over euthanasia has suddenly exploded into front-page news. Doctors are now beginning openly to admit what the profession once kept secret: that doctors sometimes kill patients who ask to die, or help such patients to kill themselves. ${ }^{49}$

Then, to illustrate his point that euthanasia 'has provoked intense controversy' not only in the Netherlands but in America and elsewhere, Dworkin discusses two cases. The first involves a New York physician who 'prescribed lethal drugs for a leukemia patient and told her how many she should take to die.' The second involves a British doctor who 'injected potassium chloride [a drug that has no analgesic effect] into a rheumatoid arthritis patient . . . begging to be killed.' ${ }^{50}$ Some 180 pages later, Professor Dworkin discusses the British case again. He then turns to what he calls 'a similar case' - the aforementioned New York case. ${ }^{51}$ I think it fair to say that the fact that the British doctor performed active euthanasia and that the American doctor only helped his patient commit suicide (and, arguably, 
provided a relatively low level of assistance at that) ${ }^{52}$ does not interest Dworkin. What does seem to bother him is that the British doctor was convicted of attempted murder while the American doctor, who was involved in 'a similar case,' was not even prosecuted.

Even if one believes (as Dworkin, Humphry and others evidently do not) that there is an important distinction between assisted suicide and active voluntary euthanasia in principle, it will be extremely difficult to contain that principle in any subsequent litigation or to adhere to the distinction in practice.

If a patient's inability to commit suicide 'for either physiological or psychological reasons' entitles her under certain circumstances to the active intervention of another person in order to bring about her death, ${ }^{53}$ why should not a patient's inability - despite preliminary assistance - to perform the last death-causing act, for either physiological or psychological reasons, entitle her to active voluntary euthanasia? If assisted suicide is appropriate when patients 'need more help from the physician than merely abating treatment, but less help than would be required if they were asking the physician to kill them, ${ }^{\prime 4}$ why is not active voluntary euthanasia appropriate when less help than 'killing them' would not suffice, when patients are unable to perform the ultimate act and thus nothing less than 'killing them' is required to 'help' them die an 'easy' death?

Suppose a patient is unable to swallow the pills that will bring about her death or is otherwise too weak to perform the last act that will fulfill her persistent wish to die. If there is or ought to be a right to assisted suicide, how can it be denied to such a person simply because she lacks the physical capacity to perform the final act by herself?

Dr Timothy Quill, who helped a long-standing patient die by suicide, does believe in drawing a line between assisted suicide and voluntary euthanasia, ${ }^{5 s}$ but even he has a difficult time adhering to that line. Quill tells, approvingly, a 'moving story' about a physician who prescribed barbiturates to a patient in an advanced stage of AIDS but who did not 'abandon his patient' when this help proved inadequate:

The patient wanted to take the barbiturates he had saved for an overdose, but was too weak to feed them to himself. Faced with this moment of truth, the doctor helped his patient swallow the pills. ${ }^{56}$

Can (should) the right to assisted suicide be confined to the terminally ill? To those suffering unbearable pain?

One can understand an argument without accepting it. I understand the basic argument for assisted suicide (and perhaps active voluntary euthanasia as 
well): Life has value only so long as it has meaning for the person whose life it is and respect for 'self-determination' and 'personal autonomy' should entitle a competent person to decide for herself whether, when and how she chooses to end her life. If this argument is convincing, however, I have great difficulty understanding why the 'right' or 'liberty' to assisted suicide should be limited to the 'terminally ill' and/or those suffering unbearable pain.

If one is trying to establish a right to assisted suicide it is good tactics to frame the issue narrowly - to speak, for example, only of a right to assisted suicide for the terminally ill. Thus, lawyers for the American Civil Liberties Union (ACLU) have challenged the constitutionality of Michigan's ban on assisted suicide insofar as it prohibits terminally ill patients from committing suicide by making use of physician-prescribed medications. ${ }^{57}$ But is there any principled way to so limit the right? If either autonomy or the merciful termination of an unendurable existence is the basis for this right, why limit it to the terminally ill?

First of all, 'there is, in fact, no consensus on what is a "terminal condition." "Fs For example, although many states still define such a condition as one that will shortly result in death regardless of the utilization of available medical treatment, several states have recently adopted provisions defining the condition as one that will soon cause death in the absence of medical intervention. ${ }^{s 9}$ Even if we could all agree on a definition of 'terminal condition,' however, 'under a variety of circumstances life may be unendurable to a reasonable person, even though he does not face the prospect of immediate and painful death.' ${ }^{60}$

Timothy Quill, one of the most eloquent proponents of physician-assisted suicide, would limit the right in various ways, but he would not confine it to the terminally ill. The patient must have a condition, he tells us, 'that is incurable and associated with severe, unrelenting suffering. ${ }^{31}$ Dr Quill does 'not want to arbitrarily exclude persons with incurable, but not imminently terminal progressive illness, such as ALS (motoneurone disease) or multiple sclerosis. ${ }^{\prime 2}$ But is it any less arbitrary to exclude the quadriplegic? The victim of a paralytic stroke? A person afflicted with severe arthritis?

If personal autonomy and the termination of suffering are the key factors fueling the right to assisted suicide, why exclude those with non-terminal illnesses or disabilities who might have to endure greater 'unbearable suffering' for much longer periods of time than those who are likely to die in the near future? Why does not a person who must continue to live what she considers an unendurable existence for ten or twenty more years have an equal - or even greater - claim or the liberty interest in assisted suicide than those with terminal conditions? ${ }^{63}$ 
In an effort to distinguish the terminally ill from all others who might seek death by suicide, Professor Sedler maintains that 'the state cannot assert any valid interest' in requiring a terminally ill person to wait until death comes naturally because "there can be no valid interest in "preserving life" when there is no "life left to preserve." "64 I really do not understand this argument.

Surely, Sedler is not saying that one who is terminally ill is no longer a 'person' or a 'human being'? Such a person may have a number of months to live (a common definition of terminal illness is six months or less to live) and her mental powers can hardly be substantially impaired if she 'chooses' to die by suicide. For the present, at least, Sedler and his confrères are not contending that persons who are no longer competent should have a right to assisted suicide. Thus, if they prevail, and their ground rules are adopted, assisted suicide could take place only if the person seeking such a death retains sufficient decision-making capacity to exercise a voluntary, competent choice. How can it be said that such a person has "no "life left to preserve"'?

Of course, such a person may feel or honestly believe that her life is not a 'life' worth preserving. But so too may many others who suffer from debilitating illnesses or severe disabilities, but who are not terminally ill.

As I understand the position of those advocating a constitutional right to assisted suicide, one should have the same right to enlist the aid of others in dying by suicide as one presently has to refuse or to withdraw life-sustaining medical treatment. ${ }^{65}$ If so, it is fairly clear that once established the right to assisted suicide would not be restricted to the terminally ill. For, as demonstrated by the Elizabeth Bouvia case and other decisions involving quadriplegics who apparently had long life expectancies, the right to refuse or to reject medical treatment has not been so limited. ${ }^{66}$ (Nor, for that matter, has it been limited to the presently competent.)

Another restriction often placed on the right to assisted suicide is that the person asserting this right must be experiencing 'intractable pain' or undergoing 'unbearable suffering.' At first blush this appears to be a small, easily identifiable group. But a closer look reveals this is not so.

First of all, although 'pain' and 'suffering' are often lumped together, the two classifications are not identical. 'Not all pain leads to suffering (the pain of the victorious distance runner leads to pleasure), nor does suffering require the presence of physical pain (the anguish of knowing one has Alzheimer's disease). ${ }^{67}$

If 'pain and suffering' means or includes physical pain, experts in the field maintain that, although pain is admittedly notoriously undertreated in America, ${ }^{68}$ 'almost all terminally ill patients can experience adequate relief with currently available treatment. ${ }^{39}$ Thus a renowned pain control expert, 
the Memorial Sloan-Kettering Cancer Center's Kathleen Foley, reports:

We frequently see patients referred to our Pain Clinic who have considered suicide as an option, or who request physician-assisted suicide because of uncontrolled pain. We commonly see such ideation and request dissolve with adequate control of pain and other symptoms, using combinations of pharmacologic, neurosurgical, anesthetic or psychological approaches. ${ }^{70}$

To be sure, '[d]ying patients often undergo substantial psychological suffering that is not fully or even principally the result of physical pain. ${ }^{, 71}$ But suffering 'has no objective correlation with a patient's (medical) condition"72 - it is 'variable from person to person' and 'externally unverifiable. ${ }^{73}$

If a right to assisted suicide were established, how could this right be denied an otherwise qualified candidate who says her pain or suffering is 'unbearable'? As a practical matter, would we not defer to the patient's own assessment of her pain or suffering? As a matter of principle, shouldn't we?

So long as a person is competent and her desire to enlist the aid of others in dying by suicide is firm and persistent, why should her 'right' to end her life in the manner she chooses (if such a right exists) be denied because her condition does not satisfy someone else's standard of suffering?

Once a right to assisted suicide is established, any requirement that the patient experience intolerable suffering will probably turn on the patient's own view of her suffering - or drop out entirely. In a sense, the requirement has already dropped out. The Washington and California proposals to legalize 'physician aid-in-dying' required only that a 'qualified patient' be afflicted with a terminal illness and express an enduring request for physician intervention. Of course, such a patient need not be suffering from a painful terminal illness or, if she is, might be receiving analgesic medications that, even by the patient's own admission, adequately relieve her physical pain.

As ethicist Albert Jonsen recently observed, the language of legislative proposals, such as those defeated in Washington and in California, is strong evidence that 'fear of uncontrolled pain' (and, I would add, 'unbearable suffering')

is no longer a major feature of the justifying arguments [for 'aid-in-dying']. Autonomy, not pain or its merciful alleviation, is the principal and even sole justifying argument offered by modern proponents. Opponents who argue, as in the Washington and California campaigns, that modern methods of pain control can virtually eliminate the category of 'intractable' pain are correct enough, but they miss the mark: the right to choose death, not the presence of pain, is now the issue. ${ }^{74}$ 


\section{THE NEED FOR A COURT TO CONSIDER THE BROAD IMPLICATIONS OF A 'NARROW' RIGHT TO ASSISTED SUICIDE FOR THE TERMINALLY ILL}

Professor Sedler tells us that the constitutional challenge he and his ACLU colleagues have mounted against Michigan's anti-assisted suicide law is 'specific and narrow' - whether the law is invalid insofar as it prohibits the terminally ill from obtaining medications from physicians that will enable them to commit suicide - and that the courts should address only this particular issue. ${ }^{7 s}$ Indeed, he goes so far as to say that the kind of 'slippery slope' arguments I have made have 'no place' in constitutional litigation and cannot be utilized 'to avoid' facing and confronting the specific question he and his colleague have framed. ${ }^{76}$ :

I could not disagree with him more. I do not believe a court can responsibly face and confront the 'narrow' issue presented without considering the general implications of the asserted right - without taking into account the 'slippery slope' arguments I have made (if one wants to call them that).

I have contended that drawing a line between the terminally ill and other seriously ill or disabled persons (who may have to endure more pain and suffering for a much longer period of time) is neither sensible nor principled. I have maintained, too, that the same may be said for drawing a line between assisted suicide (for those who need some assistance from a physician) and active voluntary euthanasia (for those who need a physician to perform the last, death-causing act). Is a judge supposed to put on blinders and forge straight ahead without thinking about the consequences and ramifications of her 'narrow' and 'specific' holding? Is this the way we are supposed to go about resolving constitutional issues?

As the three justices who played the decisive role in reaffirming Roe v. Wade observed:

Consistent with other constitutional norms, legislatures may draw lines which appear arbitrary without the necessity of offering a justification. But courts may not. We must justify the lines we draw. 7 -

An eminent constitutional law professor, Herbert Wechsler, has felicitously spelled out this important point:

[T] he main constituent of the judicial process is precisely that it must be genuinely principled, resting with respect to every step that is involved in reaching judgment on analysis and reasons quite transcending the immediate result that is achieved. To be sure, the courts decide, or should decide, only the 
case they have before them. But must they not decide on grounds of adequate neutrality and generality, tested not only by the instant application but by others that the principles imply? ${ }^{78}$

Professor Sedler is unable to find any 'principled difference' in the applicable constitutional doctrine between 'the right of a terminally ill person' to withhold or to withdraw life-sustaining medical treatment and the right of such a person to enlist the aid of a physician in committing suicide. ${ }^{79}$ It is now fairly clear, however, that the fact that a person may be kept alive for many years (for example, a respirator-dependent quadriplegic whose mental powers are unimpaired) is not a sufficient reason to deny her the right or liberty to terminate life support. ${ }^{80}$ Why, then, if a right to assisted suicide exists for the terminally ill, should it be denied to those who may be kept alive for many years? Whatever the answer, is it not appropriate for a judge to consider this question before deciding whether there is a right to assisted suicide for the terminally ill?

In arguing that there is a right to personal autonomy that encompasses the right to assisted suicide, Professor Sedler and his colleagues rely very heavily on the US Supreme Court's abortion cases. Physician-assisted suicide was not, of course, the issue before the Court in any of those cases. If it is appropriate to transcend the 'narrow' and 'specific' issue presented in a case once it is decided, and to dwell instead - and to build on - its broad implications, why is it improper to anticipate the implications of a soon-to-be decided case and to call the court's attention to them?

That a proponent of the right to assisted suicide would speak only of - and wish the courts to think only about - such a right for the terminally ill is quite understandable. Such a narrowly circumscribed claim causes less alarm and commands more general support than does a broader right to assisted suicide. And, as Justice Frankfurter once observed, 'the function of an advocate is to seduce. ${ }^{81}$

But the function of a court is to resist seduction, to rest its judgment on a principle of general significance that may be consistently applied, and to produce an intellectually coherent reason for a result which in like cases will produce a like result. If so, how can a conscientious judge avoid considering what other fact situations not presently before the court are (or are not) like cases? If I may quote Justice Frankfurter a second time:

I am aware that we must decide the case before us and not some other case. But that does not mean that a case is dissociated from the past and unrelated to the future. We must decide this case with due regard for what went before and no less regard for what may come after. ${ }^{82}$ 
Robert Sedler is part constitutional law commentator and part constitutional litigator. In his first article on the subject Sedler-the-litigator appeared to dominate - he refused to consider whether a right to assisted suicide would or should extend beyond terminally ill persons. But in a more recent article, Sedler-the-commentator seems to have come to the fore - this time Professor Sedler does address the issue. He concludes that the right would and should be available not only to those who have 'no life left to preserve' (his characterization of the terminally ill), but to some who do have 'life left to preserve' (for example, the person debilitated by multiple sclerosis who may live for several additional years) ${ }^{83}$ Comments Sedler:

The claim of the multiple sclerosis victim that for him life has become unendurable, like the claim of the terminally ill person seeking to hasten inevitable death, is objectively reasonable ... [S] ince the multiple sclerosis victim is helpless to bring about his own death, a ban on physician assistance to enable him to die so is obviously an undue burden on his right to end an unendurable life. ${ }^{84}$

Is Sedler's claim that there is or ought to be a right to assisted suicide for the terminally ill at bottom only one aspect of a claim that there is or ought to be such a right for any competent adult whose wish to die by suicide is 'objectively reasonable'? If so, why stop with the victim of multiple sclerosis? As already pointed out, there are all sorts of reasons why life may seem intolerable to a reasonable person. ${ }^{85}$ 'To argue that suicide is rational to escape physical pain [or, I would add, to end a physically debilitated life], but not suicide for any other reason, is to show oneself out of touch with the depth and complexity of human motives. ${ }^{86}$ Moreover, all sorts of seriously ill or severely disabled persons may have an 'objectively reasonable' wish to die, though they may be physically or psychologically unable to bring about their own deaths. They, too, may need someone else to perform the 'last act.'

How do we go about determining whether a competent person's firm conclusion that life has become 'intolerable' is 'objectively reasonable'? Do we turn to the writings of philosophers (many of whom are in disagreement on this point)? Do we conduct opinion polls?

Moreover, if self-determination or personal autonomy is the major force driving the right to assisted suicide, why should a competent person's firm conclusion that life has become unendurable for her have to be 'objectively reasonable'? Why should not a competent person's own evaluation of her situation suffice?

I think it noteworthy that when a Michigan trial judge recently held that there is a constitutional right to assisted suicide - so far as I am aware, the first 
American court squarely ever to do so - he drew a line neither $(a)$ between terminally ill people seeking to die by suicide and others wishing to do so nor (b) between those experiencing severe 'pain and suffering' and others whose pain and suffering was, or could be brought, under control. It is to this decision that I now turn.

\section{THE MICHIGAN EXPERIENCE}

In February I993, shortly after the number of people Jack Kevorkian had helped to commit suicide had risen to fifteen, the Michigan legislature passed a law making assisted suicide a felony, punishable by up to four years in prison. The new law prohibits one with knowledge that another person intends to commit suicide from 'intentionally providing the physical means' by which that other person does so or from 'intentionally participat[ing] in a physical act' by which she does so. ${ }^{87}$

Thë law contains a number of exceptions. It recognizes the right to reject unwanted medical treatment, even life-sustaining procedures, by specifically excluding 'withholding or withdrawing medical treatment' from its coverage. It also recognizes the principle of 'double effect' - that there is a significant distinction between the intended effects of one's actions and the unintended though foreseen effects. It does so by exempting 'prescribing, dispensing or administering' medication or treatment designed 'to relieve pain or discomfort and not to cause death, even if the medication or procedure may hasten or increase the risk of death.' (Of course, if the medication administered were designed to cause death, at the patient's request, it would be a case of active voluntary euthanasia.)

These provisions led a prominent authority on legal issues in medicine, George Annas, to say that, given its exceptions, the Michigan law was likely to withstand constitutional challenge. ${ }^{88}$ I would have put it even more strongly. But before the year was out, in People v. Kevorkian, Wayne County Circuit Judge Richard Kaufman ruled that the law violated the constitutionally protected 'right' or 'liberty' to assisted suicide. ${ }^{89}$

According to Judge Kaufman, (a) under certain conditions a competent adult has a right to commit 'rational' suicide and $(b)$ a total ban against assisted suicide 'unduly burdens' this right. ${ }^{90}$ Although the right is limited, it is not confined to the 'terminally ill.' Nor does it require unendurable 'pain and suffering.' Indeed, Judge Kaufman made no effort to distinguish between those experiencing intolerable pain and suffering and those whose pain or suffering was, or could be brought, under control.

The key factor, according to Judge Kaufman, is the presence or absence of 
'an objective medical condition' that is 'extremely unlikely to improve.' If a person's quality of life is significantly impaired by such a medical condition, even though it is not a life-threatening condition (presumably blindness, the loss of a hand or permanent paralysis of a part of the body), and her decision is made without undue influence, she may avail herself of the newly discovered right. But if a person's quality of life is significantly diminished for any other reason (for example, disgrace, financial ruin, the loss of one's entire family in an airplane crash), she may not invoke the right - no matter how competent she is or how firm and persistent her desire to die.

Many in the media reported that Judge Kaufman had drawn a line between 'rational' assisted suicide (which a state cannot prohibit) and the 'irrational' kind (which a state may prevent). But this is not quite accurate. At one point in his opinion, Judge Kaufman did express the view that if an adequate, meaningful line can be drawn between rational and irrational suicide, the liberty provision of the Due Process Clause protects a person's decision to commit rational suicide. ${ }^{\prime 1}$ But the line he ultimately drew is not a line between 'rational' and 'irrational' suicide. Rather, it is a line between one category of 'rational' suicide - would-be suicides whose lives are significantly impaired by irreversible medical conditions - and other categories of 'rational' suicide.

Judge Kaufman did not say that a suicide by one whose life is substantially impaired by a medical condition constitutes the only form of 'rational' suicide. He concluded, however, that such suicides are the only ones that may safely be afforded constitutional protection.

This is the line that must be drawn, Judge Kaufman told us, 'since any form of rational suicide that did not include the presence of an objective medical condition would be too close to irrational suicide. ${ }^{92}$ If constitutional protection were extended to all persons who have a rational wish to die "the possibility that irrational suicide would increase is too great.' ${ }^{93}$ Thus, the state may prohibit not only 'irrational' suicide and assisted suicide, but some classes of 'rational' suicide and assisted suicide as well - those 'where no objective medical condition is present.'

In his extensive discussion of the 'rationality' of suicide, Judge Kaufman relied heavily on the writings of Alfred Alvarez (an historian of attitudes toward suicide) and Richard Brandt (a prominent American philosopher). So far as I can tell, however, neither commentator would draw the line where Judge Kaufman did. For example, in a passage that Judge Kaufman quotes with apparent approval, Professor Brandt observes:

If we look over a list of the problems that bother people, and some of which various writers have regarded as good and sufficient reasons for ending life, 
one finds (in addition to serious illness) things like the following: some event which has made one feel ashamed or has cost one loss of prestige and status; reduction to poverty as compared with former affluence; the loss of a limb or physical beauty; the loss of sexual capacity; some event which makes it seem impossible that one will achieve things by which one sets store; loss of a loved one; disappointment in love; the infirmities of increasing age. It is not to be denied that such things can be serious blows to one's prospects of happiness. ${ }^{94}$

After discussing the views of the ancient Greeks and Romans, the Old Testament and early Christian doctrine, Judge Kaufman concludes that 'there is significant support in our traditions and history for the view approving suicide or attempted suicide. ${ }^{95}$ If Judge Kaufman is right about this (though I doubt that he is), his own opinion makes plain that such historical support was not limited to suicide by those whose quality of life was significantly impaired by an objective medical condition. Thus, in a passage that Judge Kaufman quotes, Alfred Alvarez observes:

According to Justinian's Digest suicide of a private citizen [during Roman times] was not punishable if it was caused by 'impatience of pain or sickness, or by another cause,' or by weariness of life . . lunacy, or fear of dishonor. Since this covered every rational cause, all that was left was the utterly irrational suicide 'without cause,' and that was punishable . . 96

In the course of his opinion, Judge Kaufman sets forth and rejects an argument I made in a recent article - that the social sanctioning of 'rational' suicide and assisted suicide is likely to lead to an increase in 'irrational' (or coerced or 'manipulated') suicide and assisted suicide. ${ }^{97} \mathrm{He}$ dismisses this argument on the ground that I did not provide any support for it. 'Couldn't one as effectively claim,' asks Kaufman, 'that by drawing a clear legal line between rational suicide and irrational suicide, the stigma of committing irrational suicide would increase?'98

Is this line of reasoning persuasive? Does it find any support in our recent experience with the 'right to die'? Until the recent legal assault on laws prohibiting assisted suicide, many of us thought we had drawn a fairly clear legal line - between the refusal or rejection of life-sustaining medical treatment and the active intervention of another to promote or to bring about death. So far as I know, however, nobody has suggested that drawing such a line has increased the stigma of assisted suicide or active voluntary euthanasia. Quite the contrary. At this very moment the firmly established right to refuse or to withdraw medical treatment is being used as a lever - as an argument for expanding the 'right to die' to include assisted suicide and active voluntary euthanasia as well. ${ }^{99}$ 
Does Judge Kaufman (or anybody else for that matter) really believe that affording constitutional protection to one form of 'rational' suicide and assisted suicide will increase the stigma attaching to 'irrational' suicide? (Or the stigma associated with other forms of 'rational' suicide?)

In writing the article Judge Kaufman quotes from, I relied heavily on the studies of geriatric psychiatrists (who work with suicidal people every day) and suicidologists (who perform 'psychological autopsies' of people who commit suicide). They report that a suicide rarely occurs in the absence of a major psychiatric disorder and that this observation is equally true in suicides among the elderly. ${ }^{100}$ More significant for our purposes, these experts underscore the inability of depressed persons to recognize the severity of their own symptoms and the failure of primary physicians to detect major depression, especially in elderly patients. ${ }^{101}$

'Ageism' - the prejudices and stereotypes applied to the elderly solely on the basis of their age - may manifest itself in a failure to recognize treatable depression, the view that an elderly person's desire to commit suicide is more 'rational' than a younger person's would be, or, more generally, the attitude that the elder has every reason to be depressed. ${ }^{102}$ As one authority has pointed out: 'Although we shrink from the idea of elderly suicide and euthanasia, we encourage it by our neglect and indifference. ${ }^{103}$ As another commentator has observed:

Suicidal persons are succumbing to what they experience as an overpowering and unrelenting coercion in their environment to cease living. This sense of coercion takes many familiar forms: fear, isolation, abuse, uselessness, and so on. ${ }^{104}$

Is it not fair to assume, as I do, that these pressures will intensify in a society that sanctions assisted suicide (and thereby suicide as well)? Is it not fair to assume that once assisted suicide is a lawful alternative and people are 'doing it' and free to talk about it, more people, especially the sick and the old and the vulnerable, will see this as the unselfish course to take - a tempting way to spare both oneself and one's family the burdens of serious illness and/or advanced age?

Of course, I cannot prove that in a suicide-permissive society a substantial number of people who otherwise would not have pursued this route will be encouraged or pressured or 'manipulated' into choosing death by suicide or assisted suicide. ${ }^{105}$ But then Judge Kaufman offers no support for his view that if a line were not drawn 'requir[ing] the presence of objective medical findings, the possibility that irrational suicide would increase is too great. ${ }^{106}$

If a judge can deny constitutional protection to some forms of 'rational' assisted suicide out of concern that if he did not do so 'irrational' assisted 
suicide might get out of hand, why can a legislature not prohibit all forms of 'rational' assisted suicide on the same ground? If a judge may give weight to the writings of philosophers in arriving at his conclusions about the 'rationality' of suicide (Judge Kaufman quotes philosopher Richard Brandt six times, three times at considerable length), why can a legislature not rely on the studies and published findings of suicidologists and geriatric psychiatrists to reach a different conclusion?

After all, as one commentator said (and I am happy to report that he is a philosopher):

If philosophers have something to say to the law, so also has the law something to say to philosophers. Attention to the working, or the possible working, of any institution or principle may well give us insight into weaknesses which remain concealed so long as it is posed in sufficiently abstract terms. ${ }^{107}$

\section{SOME FINAL THOUGHTS}

When I first wrote about this subject, thirty-six years ago, the chance that any state would legalize active voluntary euthanasia seemed minuscule and the possibility that any court would find the right of active voluntary euthanasia protected by the Due Process Clause seemed so remote as to be almost inconceivable. Not any more.

Before this decade ends I believe there is $(a)$ a strong probability that at least several states will decriminalize active voluntary euthanasia (no doubt under the euphemistic label 'aid-in-dying'); and (b) a distinct possibility that at least several appellate courts will announce a state or federal constitutional right to active voluntary euthanasia. I continue to believe the US Supreme Court will not discover or recognize such a right, but the possibility that it may can no longer be disregarded.

What we cannot do in one step - perhaps even think about doing - we can often do in two or three or four. The modern history of our activities and beliefs about the law and ethics of death and dying is a good illustration - it is 'a history of lost distinctions of former significance'108 (e.g. 'extraordinary means' versus 'ordinary means,' the respirator versus the feeding tube).

My colleague Carl Schneider has called this step-by-step process 'a psychological aspect of slippery slopes': They work partly by 'domesticating one idea' (say, disconnecting the respirator) and thus making its nearest neighbor (terminating 'artificial' feeding) 'seem less extreme and unthinkable.'109

What many used to call 'negative' or 'passive' euthanasia has become a fait 
accompli in modern medicine. The next sequence of events is likely to be physician-assisted suicide for $(a)$ the terminally ill, $(b)$ those with an 'objective medical condition' that significantly diminishes the quality of life, and (c) those whose wish to die is 'objectively reasonable.' If so, as this progression unfolds, active voluntary euthanasia will become more thinkable, more tenable and more supportable.

Proponents of an expansive 'right to die' have had considerable success in overcoming resistance step by step, blotting out one distinction after another. And there is no reason to think that this process will come to a halt. One important distinction remains - and it is not the distinction between assisted suicide and active voluntary euthanasia. As I have tried to show, this distinction is too thin to endure for very long. Indeed, even now, it is a distinction that the media, the public and even many commentators on the subject are either unable or unwilling to take seriously.

The one formidable distinction that remains is the one that is presently under attack - 'the historic divide'110 between the termination of medical treatment and the active intervention of another to promote or to bring about death. If opponents of active voluntary euthanasia are unable to defend the bridge spanning this divide, they will have lost the war. For if this bridge falls, the flimsy bridge between assisted suicide and active voluntary euthanasia seems sure to follow.

\section{AFTERWORD}

In April 1994 I finished my chapter and sent it to the editor of this collection for publication. But the last eight months of 1994 turned out to be an extraordinarily eventful time for those interested in the law, politics and ethics of assisted suicide.

Some may regard the Oregon voters' approval on 8 November of a measure (Ballot Measure I6) authorizing physicians, under certain conditions, to prescribe lethal medication for competent, terminally ill adults who request $\mathrm{it}^{111}$ as the most significant event of I994. I think not.

After losing two hard-fought campaigns by fairly close votes in the states of Washington (I99I) and California (1992), ${ }^{112}$ proponents of assisted suicide were bound to prevail in some state sooner or later. Unlike the proposals which failed earlier, the Oregon measure requires that medication prescribed under the Act be self-administered. ${ }^{113}$ Moreover, as discussed earlier, writing a prescription for a lethal medication that a patient might take to end her life is a relatively low level of assistance. ${ }^{114}$ 
It is not at all clear what bearing, if any, the Oregon vote has on the question of whether there is a constitutional right or liberty to assisted suicide. It may even work against the establishment of such a right or liberty.

For one thing, the Oregon vote demonstrates again that when American voters actually cast their ballots, they are closely divided on the issue: The more extensive Washington and California proposals failed by a 54 percent to 46 percent vote; the considerably more limited Oregon proposal barely passed by a 5 I percent to 49 percent margin. Moreover, the fact that proponents of assisted suicide finally gained a victory in Oregon could conceivably lead a Justice who favors some form of physician-assisted suicide as a matter of public policy to decline to constitutionalize the area. He or she might do so for the reason that judicial intervention at this time might halt a political process that is viewed as moving in the right direction and prolong divisiveness and defer stable settlement of the issue. ${ }^{115}$

More noteworthy in 1994, I think, than the approval of the Oregon measure were events that occurred in the courthouse of Seattle, Washington, and the state of Michigan.

On 2 May a jury acquitted Dr Jack Kevorkian of violating Michigan's prohibition against assisted suicide. Although some hailed the acquittal as proof that no jury would ever convict Kevorkian, I believe (on the basis of the jury's requests to re-examine certain evidence and various jurors' post-verdict statements to the press) that the outcome turned more on geography and semantics than it did on jury nullification. ${ }^{116}$

The very next day, the Chief Judge of the US District Court in Seattle, Washington, Barbara Rothstein, became the first federal judge to strike down a statute outlawing assisted suicide on Fourteenth Amendment due process grounds. In Compassion in Dying v. Washington, ${ }^{117}$ she invalidated a Washington state law prohibiting assisted suicide insofar as it placed an undue burden on competent, terminally ill adults who seek physician-assisted suicide.

Judge Rothstein deemed a terminally ill person's right to choose physician-assisted suicide no less intimate or personal a decision and no less deserving of constitutional protection than a pregnant woman's right to choose abortion. In the main Judge Rothstein adopted the reasoning of the Michigan Civil Liberties Union as set forth in Robert Sedler's article. ${ }^{118}$ Judge Rothstein made no more effort than did Professor Sedler to reconcile her expansive reading of the abortion cases with Bowers v. Hardwick, a case that upheld a ban against consensual sodomy as applied to homosexuals. ${ }^{19}$ She, too, ignored the case entirely.

The state of Washington argued, inter alia, that a line had been drawn - 
and should be maintained - between the termination of life-sustaining medical treatment and active intervention to promote or to bring about death. But Judge Rothstein was unmoved. From a constitutional perspective, she concluded, there is no meaningful distinction between the right to refuse or to withdraw medical treatment, a course of action that results in death, and the right of a competent, terminally ill person to achieve the same end by using drugs prescribed or provided by a physician.

Only one other American Court, a Michigan trial court, had ever held that there is a constitutional right to assisted suicide. ${ }^{120}$ But on ro May the Michigan Court of Appeals reversed that court on this point. ${ }^{121}$ A 2-I majority rejected the argument that the right to suicide or suicide assistance is a 'logical extension of [the] catalog of rights' protected by the 'guarantee of personal privacy. ${ }^{122}$ Seven months later, in People v. Kevorkian ${ }^{123}$ and Hobbins v. Attorney General, ${ }^{124}$ a $5^{-2}$ majority of the Michigan Supreme Court announced its agreement with the Court of Appeals on this point, explicitly rejecting the analysis utilized in Compassion in Dying:

The advocates of assisted suicide ask us to adopt the reasoning of a recent federal decision that invalidated the State of Washington's criminal prohibition against assisted suicide [referring to Compassion in Dying] . . . We disagree with the federal court that either Cruzan or [Planned Parenthood v.] Casey preordains that the Supreme Court would find that any persons, including the terminally ill, have a liberty interest in suicide that is protected by the Fourteenth Amendment. Those who assert such a right misapprehend the nature of the holdings in those cases.

In Cruzan, the Court was able to 'assume' a protected liberty interest in the withdrawal of life-sustaining medical treatment because it was able to distinguish between acts that artificially sustain life and acts that artificially curtail life. Although some suggest that this is a distinction without constitutional significance - a meaningless exercise in semantic gymnastics - the Cruzan majority disagreed and so do we ...

... [W] hereas suicide involves an affirmative act to end a life, the refusal or cessation of life-sustaining medical treatment simply permits life to run its course, unencumbered by contrived intervention ...

... [ [P]ersons who opt to discontinue life-sustaining medical treatment are not, in effect, committing suicide. There is a difference between choosing a natural death summoned by an uninvited illness or calamity, and deliberately seeking to terminate one's life by resorting to death-inducing measures unrelated to the natural process of dying.

... In Casey, the Court was not directly concerned with the establishment of a new right, but rather with whether the Court should retreat from the right previously recognized in Roe v. Wade. In declining to overrule Roe, and 
relying heavily on the doctrine of stare decisis, the Court emphasized that abortion cases are unique...

[T] he right to commit suicide is neither implicit in the concept of ordered liberty nor deeply rooted in this nation's history and tradition. It would be an impermissibly radical departure from existing tradition, and from the principles that underlie that tradition, to declare that there is such a fundamental right protected by the Due Process Clause. ${ }^{125}$

The fact that within the space of seven months a federal district court and a state supreme court reached opposite conclusions as to whether one has a constitutionally protected 'right' or 'liberty' to obtain a person's assistance in committing suicide indicates that American courts may disagree about this issue for the next several years - until it is decided by the US Supreme Court. But on 25 May 1994 an event occurred that is likely to have a significant impact on how this issue is ultimately resolved. That day the 24 -member New York State Task Force on Life and the Law issued a $\mathrm{I} 8 \mathrm{I}$-page report unanimously rejecting proposals to legalize assisted suicide and voluntary active euthanasia. ${ }^{\mathbf{1 2 6}}$

The Task Force is an influential body whose previous legislative proposals had reflected deep respect for individual autonomy. (Seven years earlier this same group had taken the position, at a time when the issue was still hotly disputed, that the right to terminate life-sustaining medical treatment includes the right to withhold and withdraw artificial nutrition and hydration. ${ }^{127}$ ) But in 1994 the Task Force balked at crossing 'the historic divide':

In light of the pervasive failure of our health care system to treat pain and diagnose and treat depression, legalizing assisted suicide and euthanasia would be profoundly dangerous for many individuals who are ill and vulnerable. The risks would be most severe for those who are elderly, poor, socially disadvantaged, or without access to good medical care. ${ }^{128}$

The Task Force recognized that 'one can posit "ideal" cases in which all the recommended safeguards [for assisted suicide] would be satisfied: patients would be screened for depression and offered treatment, effective pain medication would be available, and all patients would have a supportive, committed family and doctor.' ${ }^{129}$ But

the reality of existing medical practice in doctors' offices and hospitals across the state generally cannot match these expectations, however any guidelines or safeguards might be framed. These realities render legislation to legalize assisted suicide and euthanasia vulnerable to error and abuse for all members of society, not only for those who are disadvantaged . . . Constructing an ideal or 'good' case is not sufficient for public policy, if it bears little relation to prevalent medical practice. ${ }^{130}$ 
In light of the fact that Task Force members considered the legalization of assisted suicide and euthanasia from different backgrounds and perspectives, the unanimity of their recommendation that the total prohibition against these practices should remain intact is surprising and, I believe, quite significant. Although some of the Task Force members were of the view that assisted suicide and euthanasia are inherently wrong, others were not. ${ }^{131}$ Indeed, members of this second group believed that in appropriate circumstances assisting a patient to commit suicide 'would manifest a physician's commitment and duty to his or her patient.'132 Nonetheless, these members concluded that legalizing assisted suicide 'would be unwise and dangerous public policy. ${ }^{133}$ They regarded 'the consequences of quietly tolerating assisted suicide as a private act of agreement between two individuals in extreme cases as profoundly different ${ }^{134}$ from the consequences of legalizing the activity:

In addition to regulating and restraining behavior, our laws also serve a highly symbolic function ... The legal prohibition, while not uniformly honored, preserves the gravity of conduct to assist suicide and prevents abuse ...

By curtailing the autonomy of patients in a very small number of cases when assisted suicide is a compelling and justifiable response [the legal prohibition] preserves the autonomy and well-being of many others. It also prevents the widespread abuses that would be likely to occur if assisted suicide were legalized. ${ }^{135}$

As might be expected from the foregoing discussion of its report, the Task Force resoundingly rejected the view that one has a 'constitutional right' to commit suicide or to obtain suicide assistance. In sharp contrast to the position taken by Judge Rothstein in the Compassion in Dying case, the Task Force drew 'a clear line' for constitutional purposes, as well as for public policy and medical practice, 'between forgoing medical interventions and assistance to commit suicide or euthanasia.'136

Although Judge Rothstein had read the 'right to die' cases as establishing a broad right to determine the timing and manner of one's death, the Task Force maintained that 'these cases stand for the more limited proposition that individuals have a right to resist bodily intrusions, and to preserve the possibility of dying a natural death. ${ }^{137}$ The report emphasized that 'the imposition of life-sustaining medical treatment against a patient's will requires a direct invasion of bodily integrity and, in some cases, the use of physical restraints, both of which are flatly inconsistent with society's basic conception of personal dignity. ${ }^{138}$ It is this right against intrusion, maintained the Task Force '- not a general right to control the timing and manner of death - that forms the basis of the constitutional right to refuse life-sustaining treatment. ${ }^{139}$ Restrictions on suicide, on the other hand, 'entail no such 
intrusions, but simply prevent individuals from intervening in the natural process of dying.' ${ }^{140}$

Although the Task Force's analysis of the 'right to die' cases may influence some members of the Supreme Court, this analysis constitutes only a small part of the report and the Justices are likely to feel this is the one aspect of the problem about which they need the least help. They are more likely to be impressed by the tone, quality, depth and documentation of the Task Force's findings, reasoning and public policy arguments.

The Court will likely be affected by the Task Force's thoughtful discussion of the 'state of vulnerability' produced by serious illness; the uncertainty in estimating a patient's life expectancy and the fallibility of medical practice generally; the severe shortcomings of current pain relief practices and palliative care; the very small number of individuals who make an informed, competent choice to die by suicide (particularly if appropriate pain relief and supportive care are provided) and who cannot achieve their goal without another person's assistance; the close link between assisted suicide and active voluntary euthanasia; the elasticity and instability of the criteria now proposed as safeguards if and when assisted suicide and euthanasia are integrated into medical practice (for example, once euthanasia becomes 'an accepted "therapy" there is a distinct possibility that patients incapable of consenting will, in certain respects, "seem the "best" candidates for the practice'); and the recognition that assisted suicide and euthanasia 'will be practiced through the prism of social inequality and prejudice that characterizes the delivery of services in all segments of society, including health care.'141

To be sure, any American legislature remains free to reject the Task Force report as a matter of public policy. But how can it be said that a legislature that is impressed by the same nonreligious arguments against assisted suicide that influenced the Task Force and arrives at the same conclusions the Task Force did has acted unconstitutionally?

\section{NOTES}

I am indebted to University of Michigan law student Marc Spindelman for valuable research assistance and for helpful comments.

I Charles Black, The People and the Court 88 (I960).

2 In re: Quinlan, 70 N.J. Io, 355 A. 2 d 647 (I976).

3 Gruzan v. Director, Missouri Department of Health, 497 U.S. 261 (1980).
4 See Quinlan, 355 A. 2 d at $665,670 \&$ n. 9. 'The assertion that rejection of life-saving medical treatment by competent patients constitutes suicide,' observes Norman Cantor, The Permanently Unconscious Patient, Non-Feeding and Euthanasia, is 
Am. J. Law \& Med. 38I, 433 (1989), 'has been uniformly rejected - usually based on a distinction between letting nature take its course and initiating external deathcausing agents.'

5 Derek Humphry \& Ann Wickett, The Right to Die 242 (First Hemlock Society ed. I990).

6 In Quinlan the state court permitted an unconscious patient to be removed from a respirator, as her family desired; in Cruzan, the Supreme Court upheld the state's power to keep an unconscious patient on a feeding tube, over her family's objection, because the patient had not left clear instructions for ending life-sustaining treatment.

7497 U.S. at 279.

$8 \mathrm{Id}$. at 279 n. 7.

9 See John Robertson, Cruzan and the Constitutional Status of Nontreatment Decisions for Incompetent Patients, 25 Ga. L. Rev. II39, II74-75 \& n. I32 (I99I).

Io 497 U.S. at 280 .

I See Louis Michael Seidman, Confusion at the Border: Cruzan, 'The Right to Die,' and the Public/Private Distinction, I99I Sup. Ct. Rev. 47, 53, 62.

I2 See, e.g., Robert Sedler, The Constitution and Hastening Inevitable Death, Hastings Center Rep., 23 no. 5 (1993), at 20. Professor Sedler is one of the lawyers challenging the constitutionality of a Michigan law which makes assisted suicide a felony.

I3 4IO U.S. II 3 (1973).

I4 $I d$. at $152-53$. But the right is not absolute. Thus, the state's compelling interest in protecting life after viability enables it to proscribe abortion during that period except when necessary to protect the mother's life or health.

I5 Id. at $157^{-58} 8$.

I6 See, e.g., Sedler, supra note 12.

17 Paris Adult Theatre v. Slaton, 4I 3 U.S. 49, 68 (1973) (a well-known obscenity case).

I $8 \mathrm{Id}$. at $68 \mathrm{n}$. I5.

I9 See, e.g., Sedler, supra note 12, at 24.

20 Bowers v. Hardwick, 478 U.S. I86, 205 (I986) (dissenting opinion).

21 Id. at 191 .

22 Sedler, supra note $\mathrm{I2}$, at 23. This view seems very close to the attitude of the Romans, who, we are told, looked on suicide 'as a carefully considered and chosen validation of the way they had lived and the principles they had lived by,' Alfred Alvarez, The Background, in Suicide: The Philosophical Issues 7, 22 (M. Battin \& D. Mayo eds. 1980).

In formulating his argument, Professor Sedler uses snippets from the Court's long opinion in Planned Parenthood v. Casey, II2 S. Ct. 279I (I992), such as "[a]t the heart of liberty is the right to define one's concept of existence, of meaning, of the universe, and of the mystery of human life.' Id. at 2807. Casey did reaffirm Roe, but so far as I am aware nobody has suggested that it overruled Bowers v. Hardwick.

Moreover, in reaffirming the 1973 abortion cases the Casey majority relied heavily on ' $t \mathrm{t}$ ]he obligation to follow precedent' and the 'indispensable' nature of 'a respect for precedent.' Id. at 2808 . Three of the Justices who voted to reaffirm Roe (none of whom was on the Court when Roe was decided) observed that '[w]e do not need to say whether each of us, had we been Members of the Court [when Roe was decided], would have concluded, as the Roe Court did, that [the weight of the State's interest in protecting the potentiality of life] is insufficient to justify a ban on abortions prior to viability ... The matter is not before us in the first instance ... 'Id. at 2817 (O'Connor, Kennedy and Souter, JJ.).

23 See Yale Kamisar, Some Non-Religious Views Against Proposed 'Mercy-Killing' Legislation, 42 Minn. L. Rev. 969, 971-73 (I958).

24 See e.g. Wayne LaFave \& Austin Scott, I Substantive Criminal Law 330 (2d ed. 1986); Alan Meisel, The Right to Die 6I-62 (1989); Lawrence Gostin, Drawing a Line between Killing and Letting Die: The Law, and Law Reform, on Medically Assisted Dying, 2 I J. L. Med. \& Ethics 94, 96 (1993); Sanford Kadish, Letting Patients Die: Legal and Moral Reflections, 80 Cal. 
L. Rev. 857,858 (1992).

25 See, e.g., Dan Brock, Voluntary Active Euthanasia, Hastings Center Rep., 22 no. 2 (I992) at IO, I4.

26 According to Thomas Marzen, 'Out, Out Brief Candle: Constitutionally Prescripted Suicide for the Terminally Il', 2 I Hastings Con. L. Q.799, 804 (1994), 'assisted suicide is separately punishable by statute in thirty states.' Marzen lists the 30 specific criminal code provisions in a long footnote, $i d$. at $804, \mathrm{n}$. 2I. The same 30 states are listed in Alan Meisel, The Right to Die: $1994 \mathrm{Cum}$. Supp. No. I at 60-6I.

According to Timothy Quill, a wellknown proponent of physician-assisted suicide, 36 states prohibit the practice. See Quill, Death and Dignity, I4I (I993). Quill is probably including those states which ban the practice under their general criminal homicide laws as well as those that do so by specific legislation. In some states which do not have specific statutes on the subject it is unclear whether assisted suicide is treated as a type of murder or manslaughter. Until recently this ambiguity reigned in the state of Michigan. It was only after several trial courts dismissed murder indictments against Jack Kevorkian for assisting in suicides on the ground that such an act was not covered by the general homicide laws of the state that the legislature enacted specific legislation on the subject.

27 See Thomas Marzen, et al., Suicide: A Constitutional Right?, 24 Duq. L. Rev. I, 68-100 (1985).

28 See Leon Kass, Is There a Right to Die?, Hastings Center Rep. 23, no. I (1993) at 34,35 .

29 American Law Institute, Model Penal Code and Commentaries, Part I, § 2 I0.5 (1985) at p. Ioo.

30 Sanford Kadish, The Model Penal Code's Historical Antecedents, Rutgers L. J. $52 \mathrm{I}$ (I988).

3I American Law Institute, Model Penal Code, Part II, § 210.5 (Official Draft, 1962).

32 See Model Penal Code (Tentative Draft No. 9, 1959) at pp. 56-57.

33 Robert Weir, The Morality of Physician-
Assisted Suicide, 17 Law, Med. \& Health Care I16, 125 (1992).

34 American Law Institute, Model Penal Code and Commentaries, Part I, \$210.5 (1985) at p. 94 .

35 Thomas Marzen, supra note 26, at 804 . As Marzen notes, $i d$. at n. 20, every American state provides for the involuntary commitment of persons who are a danger to themselves.

36 At this point, I am quoting from the language of Michigan's 1993 law against assisted suicide. See generally George Annas, Physician-Assisted Suicide - Michigan's Temporary Solution, 328 N. Eng. J. Med. I 573 (I993). See also the discussion in note 38 infra. 'Providing the means of suicide appears to be the act against which the assistance statutes are primarily directed.' Note, Criminal Liability for Assisting Suicide, 86 Colum. L. Rev 348, 360 (1986).

37 Gostin, supra note 24 , at 96.

38 As pointed out in David Watts \& Timothy Howell, Assisted Suicide Is Not Voluntary Euthanasia, $4 \circ$ J. Am. Geriatr. Soc. 1043 (1992), assisted suicide involves various levels of assistance. According to the authors, they include supplying information; writing prescriptions for lethal medication that a patient might use to kill herself; providing the physical means, i.e., the lethal dose of medication or poison itself; and 'supervising or directly aiding' the suicide, the type of involvement characterizing the activities of Jack Kevorkian. But see Glenn Graber, Assisted Suicide Is Not Voluntary Active Euthanasia, But It's Awfully Close, 4I J. Am. Geriatr. Soc. 88 (I993) (editorial).

Not surprisingly, those who favor assisted suicide but balk at active voluntary euthanasia, try to put as much distance as possible between the two concepts by comparing and contrasting relatively low levels of assistance with active euthanasia. When they speak of assisted suicide they usually talk about supplying Hemlock Society material or other information, providing a prescription or discussing required doses - but not supervising the 
suicide or intentionally furnishing the physical means by which a person dies by suicide. See e.g. Weir, supra note 33 , at 118 (emphasis added):

If a physician is involved, the difference [between assisted suicide and active euthanasia] in personal involvement is between providing a suicidal patient with a prescription that would be lethal if taken by the patient in certain amounts, compared with the physician personally administering a lethal injection to the patient at the patient's request ... A physician who responds to a patient's request for assistance in committing suicide cannot be certain, merely by providing a prescription or discussing dosage, either that the patient will follow through with the attempt at self-destruction or that the attempt at causing his or her death will actually work.

I very much doubt that supplying information about suicide is or should be viewed as 'assisted suicide' at all. I do not think any American prosecutor would try to convict someone for providing a friend or relative information that might prove useful in committing suicide - even if it could be established (and this would be extremely hard to do) that the defendant's intent was to cause death.

There is plenty of information about how to commit suicide in Derek Humphry's best-selling book, Final Exit: The Practicalities of Self-Deliverance and Assisted Suicide for the Dying ( $\mathrm{I} 99 \mathrm{I}$ ). Indeed, as the author makes plain in his Introduction, the book is aimed at helping the public and the health professional achieve death with dignity for those who desire to plan for it.' Id. at $\mathrm{r} 8$. Hundreds of thousands of copies of this book have been sold and no doubt many have been given or lent to friends and relatives. So far as I know, no prosecutions have been brought for such acts. If a prosecutor were foolhardy enough to try to convict someone of assisted suicide for lending a sick friend or relative a copy of Final Exit I think he would soon run afoul of the First Amendment.

I have not studied the other twenty-nine state laws banning assisted suicide, but I am familiar with the Michigan statute. It does not cover supplying information about suicide at all. Nor do I believe, although this is less clear, that it prohibits a physician from prescribing drugs for a sick patient who might use them to kill herself - not at least if it is a prescription for drugs that have a legitimate medical use. The statute prohibits one 'who has knowledge that another person intends [to] commit suicide' from 'intentionally' 'participat[ing] in a physical act' or 'provid[ing] the physical means' by which the other person commits suicide. I share the view that 'physicians who write prescriptions do not provide the 'physical means' to commit suicide, any more than someone who gives a person money to fill the prescription or a car to get it would provide the physical means.' Annas, supra note 36 , at 1574 .

39 George Smith, All's Well that Ends Well: Toward a Policy of Assisted Rational Suicide or Merely Enlightened Self-Determination, 22 U. C. Davis L. Rev. 275, 279-80 (r989).

40 Joseph Fletcher, Morals and Medicine 176 (1954). Fletcher was a famous medical ethicist and a prolific writer who advocated active euthanasia for some fifty years.

4I James Rachels, The End of Life: Euthanasia and Morality 86-87 (I986).

42 Raanan Gillon, Suicide and Voluntary Euthanasia in Euthanasia and the Right to Death $173-74$ (A. B. Downing ed. I969).

43 See generally Alexander Morgan Capron, Proposition I6r: What Is at Stake?, Commonweal, Sept. 1992 (Special Supp.) at 2; Rob Carson, Washington's I-r 19, Hastings Center Rep. 22, no. 2 (I992) at 7. Both the Washington state proposal to legalize 'aid in dying' (Initiative I I9) and the California proposal to do the same (Proposition 16I) failed by a 54 percent to 46 percent margin. See Alexander Morgan Capron, Even in Defeat, Proposition I6I Sounds a Warning, Hastings Center Rep. no. I (I993) at 32.

44 Derek Humphry, Dying with Dignity: Understanding Euthanasia 70 (I992).

$45 \mathrm{ld}$. at 102.

$46 \mathrm{Id}$. at 79 . 
47 Id. at I7I.

48 Id. at 159 . (Emphasis added.)

49 Ronald Dworkin, Life's Dominion: An Argument about Abortion, Euthanasia, and Individual Freedom 3 (1993). (Emphasis added.)

so See id. at 3-4. The American case involved Dr Timothy Quill, who was not prosecuted for assisted suicide, a felony in his state; the British case involved Dr Nigel Cox, who was convicted of attempted murder. See $i d$. at $184-86$.

5 See $i d$. at $184-85$.

52 See the discussion in note 38 supra.

53 Weir, supra note 33 , at 118.

54 Id.

55 See Timothy Quill, Death and Dignity: Making Choices and Taking Charge $157-60$ (I993).

$56 \mathrm{ld}$. at 137.

57 See Sedler, supra note I2, at 20.

58 Marzen, supra note 26, at 8I4.

59 See Yale Kamisar, When is There a Constitutional 'Right to Die'? When is There No Constitutional 'Right to Live'?, 25 Ga. L. Rev. I203, I2IO-II (199I) and authorities collected therein. Moreover 'terminal' is variously defined as occurring in 'a relatively short time,' 'imminent,' when treatment only 'postpones the moment of death,' when the patient is 'incurable' and/or her condition 'hopeless.' See id.; Marzen, supra note 26 , at $8 I_{4} \&$ n. 54 .

60 Alan Sullivan, A Constitutional Right to Suicide, in Suicide: The Philosophical Issues 229, 24I (M. Battin \& D. Mayo eds. 1980).

6I Quill, supra note 26, at 162. (Emphasis added.)

62 Id. (Emphasis added.)

63 See Marzen, supra note 26 , at 800 . See also Robert Wennberg, Terminal Choices 99 (1989).

64 Sedler, supra note 12 , at 24. (Emphasis in the original.)

65 See id. at 23-24.

66 See Bouvia v. Superior Court (Glenchar), 225 Cal. Rep. 297 (Ct. App. 1986). Elizabeth Bouvia was not terminally ill, unconscious, or mentally retarded. Indeed, she was 'intelligent, very mentally competent' and 'alert.' Id. at 300,305 . Nevertheless, the California Court of Appeal granted the relief she sought - removal of the nasogastric tube keeping her alive against her will. To the same effect are $M c K a y$ v. Bergstedt, 8oI P. 2d 6I7 (Nev. I990) and State v. McAfee, 385 S.E. 2d 65 I (Ga. 1989). Both cases involved respirator-dependent quadriplegics who apparently had long life expectancies.

To be sure, none of these cases were decided by the US Supreme Court, but they have been well received by lawyers, physicians, bioethicists and medico-legal commentators. Thus Professor Alan Meisel recently called the view that a patient must be terminally ill for life support to be stopped one of the 'myths' about terminating medical treatment that should be dispelled. See Meisel, Legal Myths about Terminating Life Support, rog Archives Int. Med. I497, I498-99 (I99I).

Moreover, in the Cruzan case, the Supreme Court failed to attach any significance to the fact that Nancy Cruzan was not dying or terminally ill, as these terms are usually defined. No doubt many thought that she 'might as well be dead' or that she was 'better off dead,' but if her feeding tube had not been removed (after the case was remanded and additional evidence was presented that she would have wanted to die under the circumstances), she might have been kept alive another twenty or thirty years.

67 Daniel Callahan, The Troubled Dream of Life: Living with Mortality 95 (1993).

68 Judith Ahronheim \& Doron Weber, Final Passages 99-II4 (1992). The authors note that ' $[t]$ he majority of clinicians - including cancer specialists - receive very inadequate training in pain assessment and pain management,' $i d$. at 99, and that important information about pain control for the terminally ill and other patients has only 'started to enter the curriculum of medical schools.' Id. at $1 \mathrm{I2}$.

$69 \mathrm{ld}$. at IO2.

70 Kathleen Foley, The Relationship of Pain and Symptom Management to Patient 
Requests for Physician-Assisted Suicide, J. Pain \& Sym. Management I99I; 6:289,290. Adds Dr Foley, $i d$. at 292: 'The high cost of pumps, drugs, and home care supervision on a 24-hour basis makes [pain control] only available to a limited number of patients who have appropriate health care coverage. By rationing pain management on a financial basis, patients are being forced to consider death as their only option.'

7 I Dan Brock, Voluntary Active Euthanasia, Hastings Center Rep. 22, no. 2 (I992), at Io, 16.

72 Maurice A. M. deWachter, Euthanasia in the Netherlands, Hastings Center Rep. 22, no. 2 (1992), at 23, 25 .

73 Callahan, supra note 67 , at 102.

74 Albert Jonsen, To Help the Dying Die - A New Duty for Anesthesiologists? (Editorial), Anesthesiology 78: 225, 227 (1993).

75 See Sedler, supra note 12 , at 22-24.

$76 \mathrm{Id}$. at 23.

77 Planned Parenthood v. Casey, I12 S. Ct. 279I, 28 I7 (I992) (O'Connor, Kennedy \& Souter, JJ.) (plurality opinion).

78 Herbert Wechsler, Toward Neutral Principles of Constitutional Law, 73 Harv. L. Rev. I, I5 (1959). I think it fair to say that the present Supreme Court would readily agree. As the majority observed in the recent Casey case, supra note 77, at 2814 : 'The Court must take care to speak and act in ways that allow people to accept its decisions on the terms the Court claims for them, as grounded truly in principle, not as compromises with social and political pressures having, as such, no bearing on the principled choices that the Court is obliged to make.'

79 See Sedler, supra note I2, at 24. (Emphasis added.)

80 See text at note 66 supra and accompanying footnote. Although I suspect that nowadays almost everyone would agree that there is a right or liberty to terminate either futile or excessively burdensome 'medical treatment,' sometimes the distinction between this right and the right to commit suicide (or to seek assistance in order to achieve this end) becomes exceedingly thin. By overlooking this distinction, some courts, perhaps inadvertently, may have provided support for a right to physician-assisted suicide. Consider in this regard the interesting and troublesome - case of McKay v. Bergstedt, note 66 supra.

At the age of ten, as the result of a swimming accident, Kenneth Bergstedt became a quadriplegic. He lived for the next twenty-one years with the aid of a respirator. Then, faced with the imminent death of his ill father, Bergstedt decided, as the majority put it, 80I P. 2 d at 620, that 'he wanted to be released from a life of paralysis held intact by the life-sustaining properties of a respirator ... He despaired over the prospect of life without the attentive care, companionship and love of his father.'

At this point, Bergstedt petitioned the district court for an order permitting the removal of his respirator by a person who could also administer a sedative, thereby relieving the pain that would otherwise precede his demise. In addition, he sought an order granting this person immunity from civil or criminal liability. The district court granted the relief sought.

Although Bergstedt did not survive the date of the state supreme court's opinion in his case, the court confirmed his right to remove his life support system. It rejected the view that Bergstedt's petition constituted an attempt to commit suicide or seek suicide assistance, viewing his request as simply the exercise of his right to decline medical treatment - his 'right to allow the natural consequences of his condition to occur - unimpeded by artificial barriers.' Id. at 632 .

Justice Springer dissented, arguing forcefully (and, I think, persuasively) that although the court would not recognize a right to suicide or suicidal assistance if a person were able to do the deed himself, the majority had in essence done just that in this case because of Bergstedt's disabled condition (id. at 635):

[Bergstedt's] request to forgo mechanical respirator has been made in a context sug- 
gesting that his intent may be suicidal ... [He] had been living steadily for over [twenty] years, breathing with the aid of a ventilator, until he reached a time in his life when he decided to die because, like most other suicides, life had become, temporarily at least, intolerable for him.

Relying heavily on an amicus brief filed by Thomas Marzen, a leading authority on the law of assisted suicide and the general counsel for the National Legal Center for the Medically Dependent and Disabled, the dissent maintained that although Bergstedt's breathing device had been introduced during a medical emergency by medical personnel, it had become something more than mere medical treatment. The machine had become an 'integral part' or a 'real extension' of Bergstedt's person and could no longer be regarded mere 'treatment.' See $i d$. at 635 .

8I Felix Frankfurter, $\mathrm{Mr}$ Justice Jackson, in Felix Frankfurter on the Supreme Court 509, 5 II (P. Kurland ed. 1970).

82 West Virginia State Board v. Barnette, 3 I9 U.S. 624, 660-6I (1943) (dissenting opinion).

83 See Robert Sedler, Constitutional Challenges to Bans on 'Assisted Suicide': The View from Without and Within, 21 Hastings Con. L. Q. 777, 792 (I994) (forthcoming).

$84 \mathrm{Id}$. at $792-93$.

85 See text at note 60 supra. See also the text at notes 94 and 96 infra.

86 Philip Devine, The Ethics of Homicide 199 (1978).

87 Actually, the Michigan law criminalizes assisted suicide only temporarily. It establishes a commission on death and dying which is given fifteen months to develop and submit recommendations as to legislation 'concerning the voluntary self-termination of life.' The ban against assisted suicide is automatically repealed six months after the commission makes its recommendations. For a careful, detailed analysis of the Michigan law, see Annas, supra note 36 .

88 Id. at 1574 .

89 People v. Kevorkian, No. 93-11482 (Mich. Cir. Ct. Wayne County Dec. I3, I993). Professor Sedler and his ACLU colleagues were not directly involved in this case. The ACLU and Jack Kevorkian 'have kept at some considerable distance from each other,' Sedler, supra note 12, at $2 \mathrm{I}$. In another case brought by Sedler and his colleagues, a case also on appeal, Wayne County Circuit Judge Cynthia Stephens struck down the law on technical grounds under the state constitution, but indicated that had she not been able to invalidate the law on such grounds she would have blocked its enforcement on the basis of what she called a due process right to assisted suicide. See Hobbins v. Attorney General, No. 93-306-I78 CZ (Mich. Cir. Ct. Wayne County May 20, 1993), appeal docketed, No. 164963 (Mich. App. Aug. 13, 1993). For criticism of Judge Stephens' opinion see Yale Kamisar, 'Right to Die' Can't Be the Last Word, Legal Times, June 14, 1993, at 29-3o.

90 As Thomas Marzen has observed, supra note 26 , at 808 :

Any claim that the Constitution ought properly to recognize a right to assisted suicide necessarily assumes a recognized liberty to suicide itself. Yet paradoxically, suicide is now nowhere a crime and, in this sense, the state imposes no 'burden' of any kind on completion of the act. The plea for recognition of a right to assisted suicide thus amounts to a plea for suicide of a special sort: suicide that is done with expert aid and instruction to assure its painless and certain completion.

9I People v. Kevorkian, slip op. at 33.

92 Id. at 34. (Emphasis added.)

$93 \mathrm{Id}$.

$94 \mathrm{Id}$. at $3 \mathrm{I}-32$, quoting Richard Brandt, The Rationality of Suicide, in Suicide: The Philosophical Issues I17, I23 (M. Battin \& D. Mayo eds. 1980).

95 Slip op. at 24.

$96 \mathrm{Id}$. at 2I, quoting Alfred Alvarez, The Background, in Suicide: The Philosophical Issues 7, 22 (M. Battin \& D. Mayo eds. 1980). (Emphasis added.) On the same page of his opinion, Judge Kaufman notes that ' $[t]$ he idea that one's honor or one's quality of life would allow society to 
recognize the act of suicide as not contrary to societal norms has great historical support.' (Emphasis added.)

Slip op. at 28-29, quoting Yale Kamisar, Are Laws against Assisted Suicide Unconstitutional? Hastings Center Rep., 23, no. 3 (1993), at 32, 37 .

98 Slip op. at 29.

99 See text at notes 65 and 79 supra.

I00 See James Brown, et al., Is It Normal for Terminally Ill Patients to Desire Death?, I43 Am. J. Psych. 208, 210 (Feb. 1986); Yeates Conwell \& Eric Caine, Rational Suicide and the Right to Die, $325 \mathrm{New}$ Eng. J. Med. IIOO, IIOI (Oct. I991); Herbert Hendin \& Gerald Klerman, Physician-Assisted Suicide: The Dangers of Legalization, 150 Am. J. Psychiatry I434 (1993); Roberta Richardson, et al., Coping with the Suicidal Elderly: A Physician's Guide, 44 Geriatrics 43-44 (Sept 1989).

ror See David Clark, 'Rational' Suicide and People with Terminal Conditions or Disabilities, 8 Issues in Law \& Med. 147, 155, I62 (1992); Conwell \& Caine, supra note I0O, at Iror.

IO2 See George Colt, The Enigma of Suicide 392-95 (I991); Clark, supra note Ior, at 163; Conwell \& Caine, supra note I00, at I I02; Richardson, supra note I00, at 47

IO3 Colt, supra note IO2, at 394.

104 Sociologist Menno Boldt, quoted in Colt, supra, at 342.

Io5 For a discussion of 'circumstantial' and 'societal' manipulation in the context of suicide, see Margaret Pabst Battin, $\mathrm{Ma}$ nipulated Suicide, in Suicide: The Philosophical Issues 169 (M. Battin \& D. Mayo eds. 1980).

106 Slip op. at 34.

I07 Devine, supra note 86 , at 188 .

I08 Thomas Mayo, Constitutionalizing the 'Right to Die', 49 Maryland L. Rev. I03, I 44 (1990).

I09 Carl Schneider, Rights Discourse and Neonatal Euthanasia, 76 Calif. L. Rev., 151, 168 (I988). Although Karen Ann Quinlan's parents obtained permission to remove their daughter from the respirator, they did not request permission to remove the feeding tube that was to keep her alive for another nine years. They probably declined to do so because they viewed feeding as 'natural' or 'basic' or 'ordinary' care. If the Quinlans had sought permission to remove their daughter's feeding tube, they would have run into strong resistance and most probably would have been rebuffed. For in the 1970 s the distinction between the feeding tube and other forms of life support was quite formidable. If such a case arose today, of course, the feeding tube would be removed without any fanfare. See the discussion in Kamisar, supra note 59, at $1220-24$.

IIO Albert Alschuler, Reflection, in Active Euthanasia, Religion, and the Public Debate I05, I08 (The Park Ridge Center, 1991).

III See Michael Betzold, Oregon Gives Approval; Renewed Ban Likely in Michigan, Detroit Free Press, Nov. 1o, 1994, p. 5B; William Crum, Doctors Split on Oregon's Legalization of Assisted Suicide, Ann Arbor News, Nov. II, 1994, p. A7; Timothy Egan, Suicide Law Placing Oregon on Several Uncharted Paths, N.Y. Times, Nov. 25, 1994, p. I

II2 See note 43 supra.

II3 According to Geoff Sugerman, the campaign director of Oregon Right to Die, the Oregon measure passed for this reason and because the Oregon Medical Association broke with the National Office of the American Medical Association (which opposed the assisted suicide measure) and decided to remain neutral. See Betzold, supra note III; Egan, supra note III.

114 See the discussion in note 38 supra.

II5 Cf. Ruth Bader Ginsburg, Speaking in a Judicial Voice, 67 N.Y.U. L. Rev. II85, I208 (I992): 'Roe [v. Wade] . . . halted a political process that was moving in a reform direction and thereby, I believe, prolonged divisiveness and deferred stable settlement of the issue.' This was the last article Judge Ginsburg wrote before being appointed to the US Supreme Court.

II6 Although some jurors did question the wisdom of Michigan's law against assisted 
suicide and probably would have voted to acquit Kevorkian of charges that he assisted in the suicide of Thomas Hyde whatever the circumstances, other jurors seemed genuinely uncertain as to whether the crime occurred in Wayne County (where the case was tried) or in adjoining Oakland County (where, according to Kevorkian, the crime actually occurred). The trial judge instructed the jury that unless it found beyond a reasonable doubt that the crime took place in Wayne County it had to acquit Dr Kevorkian. This instruction dealt the prosecution a heavy blow, probably a fatal one. As I have observed elsewhere, Kamisar, The Real Reason Dr Kevorkian was Acquitted, Legal Times, May 30, 1994, at 27, if I had been on the jury I could not have honestly said that the prosecution had established beyond a reasonable doubt that the crime occurred in Wayne County.

Moreover, other jurors seemed genuinely confused about the distinction between Kevorkian's motive or ulterior purpose (to relieve Hyde of his suffering) and his intent or immediate purpose (to bring about Hyde's death). Unfortunately, the trial judge failed to dispel the confusion. He might have done so, for example, by telling the jury something Lord Goff once said: 'If I kill you for your money, my intention is to kill you but my motive is to lay my hands on your money. So also, if I kill you from the motive of compassion (so-called mercy killing) I nevertheless intend to kill you ...' Robert Goff, The Mental Element in the Crime of Murder, 104 L.Q. Rev. 30, 42 (1988). But the trial judge did not attempt to differentiate intention from motive.

The need to do so was heightened, I believe, by the language of Michigan's anti-assisted suicide law. The legislature wanted to convey the message, as Michigan State University bioethicist Howard Brody expressed it, Legislative Ban on Assisted Suicide: Impact on Michigan's Medical Practice, 92 Mich. Med. 32, 33 (1993), that 'no Michigan physician should feel reluctant to provide pain or symptom-relief medication, even narcotics in very high doses, so long as the intent is to make the patient comfortable' (even if the medication increases the risk of death). Thus the law criminalizing assisted suicide contains an exception: '[This prohibition] does not apply to prescribing, dispensing, or administering medications or procedures if the intent is to relieve pain or discomfort and not to cause death, even if the medication or procedure may hasten or increase the risk of death.' (Emphasis added.) But Kevorkian does not come within this exception - when he supplies a patient carbon monoxide his intent is to cause death. The exception applies when death is a byproduct of attempts to relieve suffering by increasing the dose of narcotics; it does not apply when death is the result intended - when the defendant means to bring about death as a way to end the patient's suffering. (To say that the suicide assistance provided by Kevorkian, the person the legislators had uppermost in mind when they drafted and debated the law prohibiting assisted suicide, falls under an exception to the prohibition is to render the law a nullity.)

Another word about the Michigan law: To call what Kevorkian does (supplying a person with a lethal dose of carbon monoxide) 'administering medications or [medical] procedures' is a peculiar use of the English language. One might as well say that putting a plastic bag over a suffering patient's head in order to suffocate her is administering a medication or engaging in a medical procedure. But the trial judge shed no more light on the meaning of the statutory language 'dispensing or administering medications or procedures' than he did on the meaning of the crucial language if the intent is to relieve pain or discomfort and not to cause death.' The trial judge evidently assumed that Kevorkian's activities constituted administering medications or medical procedures and left the jury to struggle for itself over whether the de- 
fendant's 'intent' was to 'relieve' Hyde's 'pain or discomfort' (an exception to the ban) or to 'cause' his death (a violation of the law).

117850 F. Supp. 4454 (U.S.D.C., W.D. Wash., May 3, 1994). The case is on appeal.

I 18 See note 22 supra and accompanying text.

I19 See note 22 supra and accompanying text.

I20 This decision, by Wayne County Circuit Judge Richard Kaufman, is discussed at considerable length in the text at notes 89-107 supra.

I2I The court made its ruling in Hobbins $\mathbf{v}$. Attorney General, 518 N.W. $2 \mathrm{~d} 487$ (Mich. App. 1994), which had been consolidated on appeal with People v. Kevorkian. See the discussion in $518 \mathrm{~N}$.W. $2 \mathrm{~d}$ at $492-94$. However, the court of appeals invalidated Michigan's ban against assisted suicide on a technical ground - by both establishing a commission to study certain issues relating to death and dying and amending the penal code to create the crime of assisted suicide the law ran afoul of a state constitutional provision that no law shall embrace more than one object. But seven months later the state supreme court reversed the court of appeals on this point. See note 123 infra.

122 Hobbins v. Attorney General, 5 I8 N.W. $2 \mathrm{~d}$ at 492.

I23 Numbers 9959, 99674 \& 99759 (Dec. I3, 1994). The court also held that Michigan's anti-assisted suicide ban did not violate a state constitutional requirement that no law may embrace more than one object. It held, too, that even absent a statute specifically prohibiting assisted suicide, such conduct may be prosecuted as a separate common-law offense punishable by five years' imprisonment.

124 Numbers 99752 \& 99758 (Dec. 13, 1994). Hobbins and Kevorkian are summarized and extracted in 63 US Law Week 2385 , 2393-94 (January 3, 1995). Two days after the Michigan Supreme Court handed down these decisions, the Chief Judge of the US District Court for the Southern District of New York, Thomas Griesa, also rejected that argument that there is a constitutional right to assisted suicide. Quill v. Koppell, No. 94 Civ. 532 I (TPG) (U.S.D.C., S.D.N.Y., Dec. I5, 1994). The case is summarized and extracted in 63 U.S.L.W. 240I, 2406-07 (Jan. 10, 1995).

I25 Slip op. at 29-33, 35-36, 43 (Chief Justice Cavanagh, joined by Justices Brickley and Griffin). In a separate opinion, concurring in part and dissenting in part, Justice Boyle, joined by Justice Riley, 'agree[d] with the lead opinion's result and rationale that [the ban against assisted suicide] is not violative of a fundamental right protected by the Due Process Clause of the state or federal constitution.' Slip op. at 2. Planned Parenthood v. Casey, mentioned in the extracts from Chief Justice Cavanagh's lead opinion, is discussed in note 22 supra. See also Quill $\mathrm{v}$. Koppell, supra, note 124 , which also concluded that plaintiffs' reliance on Cruzan and Casey was misplaced. Quill also rejected the argument that refusal of medical treatment is essentially the same thing as committing suicide with the assistance of a physician.

I26 The New York State Task Force on Life and the Law, When Death Is Sought: Assisted Suicide and Euthanasia in the Medical Context (1994). The Task Force included eight medical doctors (two of whom were deans of medical schools), two bioethicists who were not medical doctors, four lawyers, six clergymen (one of whom was also a law professor), the state commissioner of health, the state commissioner on the quality of care for the mentally disabled and a member of the New York Civil Liberties Union. In addition, a nurse and three medical doctors served as consultants to the task force.

I27 The New York State Task Force on Life and the Law, Life-Sustaining Treatment: Making Decisions and Appointing a Health Care Agent (1987).

I28 New York State Task Force Report (1994), supra note 126, at ix (Executive Summary).

129 Id. at 120.

I $30 \mathrm{Id}$.

13 I See id. at 138-40. 
$132 I d$, at 140 .

$133 \mathrm{Id}$.

$134 I d$. at $140-41$.

$135 \mathrm{Id}$.

I36 Id. at vii (Preface) 68, 71-75. Although the Task Force report was published three weeks after the decision in the Compassion in Dying case, it was written before Judge Rothstein issued her ruling in that case.

I37 Id. at 68 .

$\mathrm{I} 38 \mathrm{Id}$. at $7 \mathrm{I}$.

I $39 \mathrm{Id}$.

I $40 \mathrm{Id}$.

I4I See id. at 72, I2I, I25, I3I-33, I45, I47. 